Animal Production in Developing Countries

Occasional Publication No. 16 - British Society of Animal Production 1993

edited by M. Gill, E. Owen, G. E. Pollott and T. L. J. Lawrence

\title{
Management strategies for minimizing environmental constraints to small ruminant production in semi-arid areas of southern Africa
}

\author{
L. R. Ndlovu and L. M. Sibanda \\ Department of Animal Science, University of Zimbabwe, PO Box MP 167, Mount Pleasant, Harare, Zimbabwe
}

\section{Introduction}

Small ruminants are an integral, and sometimes dominant, component of the agricultural systems found in semi-arid areas of southern Africa. Semiarid areas are characterized by severe fluctuations in nutrient quality and availability (Devendra, 1987). Small ruminants, particularly goats, are better able to survive these fluctuations than are large ruminants and consequently survive in large numbers after droughts compared with cattle. This enhances their importance in smallholder agriculture in southern Africa.

The current productivity of small ruminants under smallholder management in semi-arid areas of southern Africa is low (Table 1). Both pre-weaning and post-weaning growth rates observed under smallholder management are less than half of growth rates observed on station for the same breed. Similarly, kidding intervals have been found to range from 217 days to 370 days and wool production under station conditions has been found to be $4.5 \mathrm{~kg}$ per head. Thus the low productivity of smallholder flocks is not genetic but is due to management.

Season of birth has a great influence on growth of kids (Table 2) and survival (Table 3) and consequently on overall productivity. However, smallholder farming systems practised are not suitable for controlled breeding. There is a need for management strategies to alleviate seasonal effects. Provision of supplementary food in the form of legume forages is recommended. Dolichos lablab has been found to grow very well in these semi-arid

Table 1 Productivity of small ruminants in semi-arid southern Africa under smallholder management

\begin{tabular}{lcc}
\hline \hline & Goats & Sheep \\
\hline Growth (g/day) & & \\
Pre-weaning & 55 & 133 \\
Post weaning & 35 & 50 \\
90 -day weight (kg) & 7.4 & 12.0 \\
Fibre production (kg per head) & 0.80 & 2.4 \\
\hline
\end{tabular}

Table 2 Weight of kids at different ages born in different seasons

\begin{tabular}{llllll}
\hline & \multicolumn{5}{c}{ Weight (kg) } \\
\cline { 2 - 6 } & 30-day & 60-day & 90-day & 120-day & 180-day \\
\hline $\begin{array}{l}\text { Season of birth } \\
\text { November to } \\
\text { March }\end{array}$ & 3.7 & 4.7 & 6.4 & 6.8 & 9.1 \\
$\begin{array}{c}\text { April to July } \\
\text { August to }\end{array}$ & 3.3 & 4.7 & 5.8 & 7.3 & 11.4 \\
October & 3.9 & 5.3 & 7.1 & 8.7 & 11.1 \\
\hline \hline
\end{tabular}

Table 3 Effect of season of birth on survizal of kids at 180 days of age

\begin{tabular}{lc}
\hline Season of birth & Survival (\%) \\
\hline November to March & 67 \\
April to July & 60 \\
August to October & 35 \\
\hline
\end{tabular}

areas (Mahabile, Masilo and Kiflewahid, 1990) and would thus be a suitable legume forage supplement. Feeding the supplement to the young would improve growth rates to weaning whilst feeding it to lactating females would reduce post-partum anoestrus and, consequently, parturition intervals. However, land ownership is such that the amount of forage that could be produced by an individual smallholder may be insufficient for both the lactating females and the young. In such situations preference should be given to the young animals.

\section{References}

Devendra, C. 1987. Herbivores in the arid and wet tropics. In The nutrition of herbiowres (eds J. B. Hacker and J. $\mathrm{H}$. Ternouth), pp. 23-46. Academic Press, Australia.

Mahabile, W., Masilo, B. and Kiflewahid, B. 1990. Use of sorghum bran and Lablab purpurcus hay in sorghum stover based diets for crossbred cows. In Utilization of research results on forage and agricultural by-product materials as animal feed resources in Africa (ed. B. H. Dzowela, A. N. Said, Asrat Wendem-Agenehu and J. A. Kategile). International Livestock Centre for Africa, Addis Ababa, Ethiopia. 